\title{
Enterotoxin Production, DNA Repair and Alkaline Phosphatase of Vibrio cholerae Before and After Animal Passage
}

\author{
By NIRMAL K. ROY, ${ }^{1}$ GOUTAM DAS, ${ }^{1}$ T. S. BALGANESH, ${ }^{2}$ \\ SAILENDRA N. DEY, ${ }^{1}$ RANAJIT K. GHOSH ${ }^{1}$ AND JYOTIRMOY DAS ${ }^{1}$ * \\ ${ }^{1}$ Department of Biophysics and ${ }^{2}$ Department of Microbiology, Indian Institute of Chemical \\ Biology, Calcutta 700 032, India
}

(Received 2 September 1981)

Three strains of Vibrio cholerae differing in biotype, serotype and/or toxinogenicity were studied. The capability for dark repair of DNA and stability of alkaline phosphatase decreased concomitantly with toxinogenicity on laboratory passage of highly enterotoxinogenic strain 569B. These properties could be restored by passaging strain 569B once through a guinea-pig.

\section{INTRODUCTION}

Studies on the capability for repair of UV-induced DNA damage (Das et al., 1981) and repression of alkaline phosphatase (APase) (Roy et al., 1982) in Vibrio cholerae indicated that these properties might be dependent on the conditions of maintenance of the culture. It is generally observed that the virulence of pathogenic strains of classical vibrios and the amount of enterotoxin produced by them are reduced during laboratory maintenance (Craig, 1971). Animal passage of laboratory strains enhances both virulence and the level of toxin production, taking advantage of the selective mechanisms operating in vivo (Wilson \& Miles, 1975). Although several investigators have postulated that enterotoxin production might have an important role in the physiology of classical vibrios (Honda \& Finkelstein, 1979; Richards \& Douglas, 1978; Ganguly \& Greenough, 1975), no systematic work has yet been reported on the phenotypic changes occurring during laboratory maintenance of strains when the enterotoxin production decreases.

It is in this context that the present report compares enterotoxin production, the capability for dark repair of UV-induced damage to DNA and the stability of APase in three laboratory strains of $V$. cholerae before and after animal passage. The results presented show that during laboratory maintenance, DNA repair capabilities and the stability of APase were reduced along with the reduction in the toxinogenicity of strain 569B. These properties could be restored by animal passage of the strain. For comparison, similar studies were performed using nontoxinogenic strain EW6 and mildly toxinogenic strain 154 .

\section{METHODS}

Bacterial strains. The biotype and serotype of $V$. cholerae strains used in this study are listed in Table 1. All strains were obtained from the Cholera Research Centre, Calcutta, India. Cultures were maintained lyophilized or frozen at $-40{ }^{\circ} \mathrm{C}$ in nutrient broth containing $15 \%(\mathrm{v} / \mathrm{v})$ glycerol. Every 2 months the strains were passaged in guinea-pigs by injection into the intraperitoneal cavity. The animals were killed after $24 \mathrm{~h}$ and stock cultures were prepared from single colony subcultures after proper identification (Mukherjee, 1978). Laboratory strains referred to here are strains maintained on agar slants for 2 to 4 months. The strains were subcultured every 2 weeks. Cell growth was assayed by measuring $A_{540}$ in a $10 \mathrm{~mm}$ light path $\left(A_{540}=1.0\right.$ corresponds to $1.2 \times 10^{9}$ c.f.u. $\left.\mathrm{ml}^{-1}\right)$. Experiments were done using cells from the same batch culture.

Media and buffer. Cells were grown at $37^{\circ} \mathrm{C}$ with shaking (180 rev. $\mathrm{min}^{-1}$ ) either in Bactopeptone (Difco) $30 \mathrm{~g}$ per litre of distilled water or in nutrient broth containing Bactopeptone (Oxoid) $10 \mathrm{~g}$, Lab-Lemco powder (Oxoid) $10 \mathrm{~g}$ and sodium chloride $5 \mathrm{~g}$ per litre of distilled water. The $\mathrm{pH}$ of both media was adjusted to 7.5. Nutrient agar plates contained $1.5 \%(\mathrm{w} / \mathrm{v})$ Bactoagar (Difco) in nutrient broth. For the APase assay, cells were grown in 
Table 1. Characteristics of $V$. cholerae strains used

\begin{tabular}{llcl} 
Strain & Genotype & Other information & \multicolumn{1}{c}{ Reference } \\
569B & Prototroph & Classical biotype; serotype, Inaba; highly toxinogenic & Mukherjee (1978) \\
154 & Prototroph & $\begin{array}{c}\text { Classical biotype; serotype, Ogawa; mildly toxinogenic, } \\
\text { universal host for classical cholera bacteriophages }\end{array}$ & Mukherjee (1978) \\
EW6 & Prototroph & El Tor biotype; serotype, Ogawa; non-toxinogenic & Gerdes \& Romig (1975)
\end{tabular}

phosphate-depleted nutrient broth containing $0.1 \%(\mathrm{w} / \mathrm{v})$ glucose $(\mathrm{pH} 7.4)$ as described previously (Roy et al., 1982). This low phosphate medium with glucose, containing $25 \mu \mathrm{M}$ inorganic phosphate, will be referred to as LPG medium; the undepleted medium contained $2.5 \mathrm{mM}$ inorganic phosphate.

The buffer used in DNA repair experiments was $50 \mathrm{~mm}$-Tris/HCl buffer ( $\mathrm{pH} \mathrm{7.5)} \mathrm{containing} 5 \mathrm{mM}-\mathrm{MgCl}_{2}$. The buffer used for suspending cell pellets to assay APase activity was $10 \mathrm{mM}$-Tris/ $\mathrm{HCl}$ buffer $(\mathrm{pH} 8 \cdot 0)$ containing $1 \mathrm{mM}-\mathrm{MgCl}_{2}$ and $1 \mathrm{mM}-\mathrm{CoCl}_{2}$.

Toxin assay. Whole-cell lysates were used as toxin preparations in all experiments. The cell lysates were prepared by sonicating ( 14 kilocycles, $30 \mathrm{~min}$ ) $18 \mathrm{~h}$ cultures grown in Bactopeptone medium following the method of Burrows et al. (1965). In some experiments cell-free culture supernatants were also used as toxin samples. The amount of toxin produced by a culture was assayed by the rabbit ileal loop method (Kasai \& Burrows, 1966) and the vascular permeability test (Craig, 1971). Fluid accumulation in the ligated rabbit ileal loop was taken as a measure of toxinogenicity of a strain. Not more than $100 \mathrm{~cm}$ of gut measuring from anterior to appendix was used. Cell lysate or cell-free culture supernatant $(2 \mathrm{ml})$ was inoculated in four $12-14 \mathrm{~cm}$ loops. In all experiments negative (broth) and positive (animal-passaged 569B cells) control loop inoculations were included. Toxinogenicity was expressed as the ratio of the volume of fluid accumulated $(\mathrm{ml})$ to the length of the negative control loop (Kasai \& Burrows, 1966). In the vascular permeability test, $0.1 \mathrm{ml}$ of several dilutions of cell-free culture supernatant in $0.9 \%(\mathrm{w} / \mathrm{v}) \mathrm{NaCl}$ was injected intradermally in the depilated back of rabbits. In each experiment, heat-inactivated culture supernatant $\left(56^{\circ} \mathrm{C}, 30 \mathrm{~min}\right)$ was used as a control. A $5 \%(\mathrm{w} / \mathrm{v})$ solution of pontamine sky blue $6 \mathrm{BX}$ (Gurr, London) was injected intravenously $(1.2 \mathrm{ml}$ per $\mathrm{kg}$ body weight) after $24 \mathrm{~h}$. The diameter of the blue lesion was measured $1 \mathrm{~h}$ after the injection of the dye. Toxin level was expressed as the number of blueing doses per ml of culture. One blueing dose is equivalent to a blue lesion of $7 \mathrm{~mm}$ diameter (Craig, 1971).

UV irradiation conditions and dark repair. Cells in the mid-exponential phase of growth in nutrient broth or LPG medium were harvested by centrifugation $(5000 \mathrm{~g} ; 10 \mathrm{~min})$ and suspended in the buffer $\left(2-3 \times 10^{8} \mathrm{c.f} . \mathrm{u}\right.$. $\left.\mathrm{ml}^{-1}\right)$. The suspension $(5 \mathrm{ml}$ ) was irradiated in a $80 \mathrm{~mm}$ Petri dish with constant shaking in the dark, using a $15 \mathrm{~W}$ Philips germicidal lamp emitting primarily at $254 \mathrm{~nm}$ at a dose rate of $1.25 \mathrm{~J} \mathrm{~m}^{-2} \mathrm{~s}^{-1}$. The irradiated cell suspension $(0.1 \mathrm{ml})$ was assayed for c.f.u. All manipulations were carried out under red light.

For investigation of dark repair, UV-irradiated cells were held in the buffer at $37^{\circ} \mathrm{C}$ in the dark. At various times during incubation samples were assayed by viable count as described previously (Das et al., 1981).

Assay of alkaline phosphatase (APase). At intervals during growth in LPG medium, $5 \mathrm{ml}$ samples were removed. APase activity was assayed in the whole culture and in the cell pellet obtained by centrifugation at $9000 \mathrm{~g}$ for $5 \mathrm{~min}$, by monitoring the release of $p$-nitrophenol from $p$-nitrophenyl phosphate. One unit (U) of enzyme activity was defined as the amount of enzyme that liberated $1 \mathrm{nmol} p$-nitrophenol $\mathrm{min}^{-1}$ under the conditions of the assay. The reaction mixture contained $2 \mathrm{mM}-p$-nitrophenyl phosphate, $1 \mathrm{mM}-\mathrm{MgCl}_{2}$ and the enzyme in a final volume of $2 \mathrm{ml}$ $1 \mathrm{M}-\mathrm{Tris} / \mathrm{HCl}\left(\mathrm{pH} \mathrm{8.0)}\right.$ ). The reaction was carried out at $37^{\circ} \mathrm{C}$. To terminate the reaction $0.2 \mathrm{ml}$ of $26 \%$ (w/v) $\mathrm{K}_{2} \mathrm{HPO}_{4}$ was added. A sample $(0 \cdot 2 \mathrm{ml})$ of whole culture or suspension of the cell pellet was used as enzyme source. The stability of the enzyme during assay was checked following the method of Selwyn (1965). The enzyme activity was expressed as $U(\mathrm{mg} \text { dry } \mathrm{wt})^{-1}$.

\section{RESULTS AND DISCUSSION}

The toxinogenicity of three strains of $V$. cholerae before and after animal passage are summarized in Table 2. No detectable amount of toxin was produced by non-toxinogenic strain EW6 irrespective of whether the cells were animal-passaged or not. The toxinogenicity of mildly toxinogenic strain 154 did not change appreciably upon animal passage. However, strain 569B exhibited a marked increase in enterotoxin production after passage. Similar results were obtained using cell-free culture supernatants as the source of enterotoxin.

Strain 569B showed decreased viability in each of the broth media used in the present study after five to seven subcultures. The reduction of growth can be restored by animal passage (data not shown). Growth of strains EW6 and strain 154 was not affected by laboratory maintenance. 
Table 2. Enterotoxinogenicity of $V$. cholerae before and after animal passage

Each value represents the mean of at least five sets of independent growth experiments and independent whole-cell lysates. The numbers in parentheses represent ranges in values.

Fluid accumulation in ileal loop

\begin{tabular}{|c|c|c|c|c|c|c|}
\hline \multirow[b]{2}{*}{ Status } & \multicolumn{3}{|c|}{$\left(\mathrm{ml} \mathrm{cm}^{-1}\right)$} & \multicolumn{3}{|c|}{ Blueing dose $\mathrm{ml}^{-1}$} \\
\hline & EW6 & 154 & $596 \mathrm{~B}$ & EW6 & 154 & $569 \mathrm{~B}$ \\
\hline $\begin{array}{l}\text { Before } \\
\text { passage }\end{array}$ & 0 & $\begin{array}{c}0 \cdot 34 \\
(0 \cdot 30-0 \cdot 38)\end{array}$ & $\begin{array}{c}0.58 \\
(0.42-0 \cdot 64)\end{array}$ & 0 & $\begin{array}{c}8 \\
(6-8 \cdot 5)\end{array}$ & $\begin{array}{c}700 \\
(630-810)\end{array}$ \\
\hline $\begin{array}{l}\text { After animal } \\
\text { passage }\end{array}$ & 0 & $\begin{array}{c}0.45 \\
(0.41-0 \cdot 56)\end{array}$ & $\begin{array}{c}1.40 \\
(0.98-1.50)\end{array}$ & 0 & $\begin{array}{c}17 \\
(16-21)\end{array}$ & $\begin{array}{c}1900 \\
(1640-2000)\end{array}$ \\
\hline
\end{tabular}

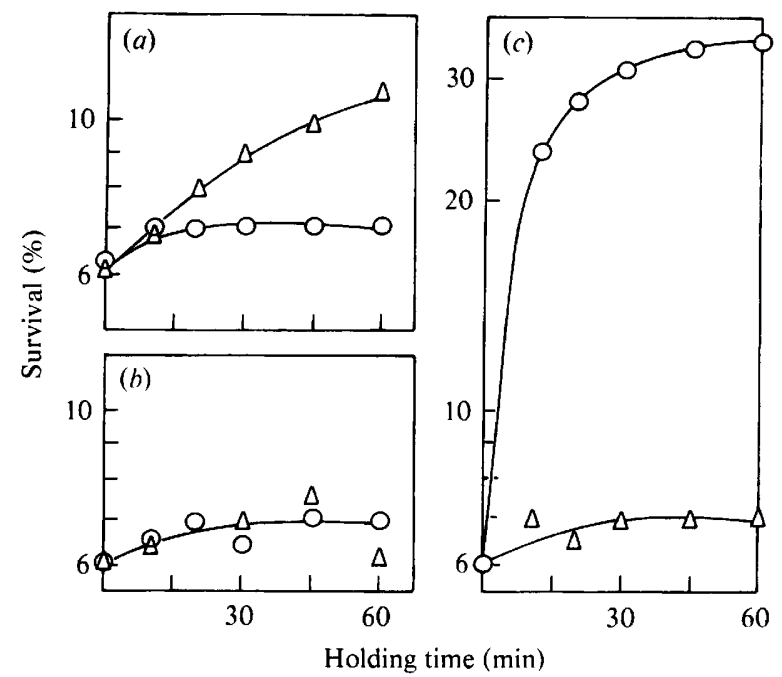

Fig. 1. Dark repair kinetics of UV-irradiated suspension of strains EW6 (a), $154(b)$ and 569B (c) before $(\triangle)$ and after $(O)$ animal passage. UV-inactivated cells were held in buffer in the dark at $37^{\circ} \mathrm{C}$ and at intervals during holding, viable counts were made. Each point is the mean value of three or four experiments; variation in values for percentage survival never exceeded $15 \%$ of the mean value.

\section{Dark repair of UV-induced DNA damage in $V$. cholerae cells before and after animal passage}

A progressive decline in the dark repair capability of strain 569B was observed upon five to seven subcultures. To examine the phenomenon in detail, cells before and after animal passage were irradiated with UV light to give a survival of $5 \%$. The UV doses required for $95 \%$ killing were 10,7 and $5 \mathrm{~J} \mathrm{~m}^{-2}$ for strains 569B, EW6 and 154, respectively. The irradiated cells were held in buffer in the dark at $37^{\circ} \mathrm{C}$ and the kinetics of dark recovery were examined by assaying the number of viable cells after different holding times.

Non-toxinogenic strain EW6 does not possess an efficient dark repair mechanism. While a twofold increase in survival was observed after holding UV-irradiated EW6 cultures, maintained in the laboratory, for $\mathbf{4 0} \mathrm{min}$ in the dark, animal-passaged cells were unable to repair UVinduced DNA damage (Fig. $1 a$ ). No dark repair of UV-induced DNA damage was observed for strain 154 after animal passage. The results show that the DNA repair capability of strain 154 was not altered during laboratory maintenance (Fig. 1 b). In contrast to strains EW6 and 154, the capability for dark DNA repair in strain 569B was abolished by subculture in the laboratory. A single passage through a guinea-pig, however, restored the DNA repair capability (Fig. 1 c). Of 30 single-colony isolates of strain 569B after animal passage, 24 showed similar recovery of DNA repair capability and in all 24 of these isolates the amount of enterotoxin produced was also enhanced. 


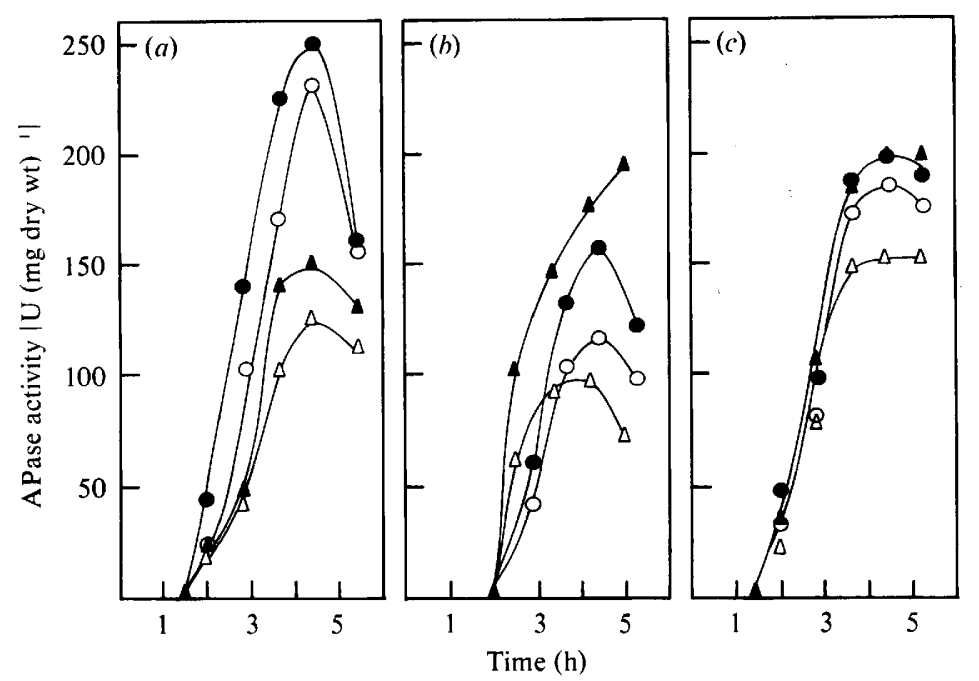

Fig. 2. APase activity in whole culture (solid symbols) and cell pellet (open symbols) of strains EW6 (a), $154(b)$ and 569B $(c)$. $\Delta, \triangle$, Activity before passage; $O, O$, activity after animal passage. The results shown are of typical experiments. Each assay was performed in triplicate; experiments were repeated at least five times and gave reproducible results.

\section{APase activity in $V$. cholerae before and after animal passage}

The activity of repressible APase and its recovery in the cell pellet were examined before and after animal passage. At different times during growth in LPG medium, cells were removed and APase activity in whole culture, cell pellet and culture supernatant was assayed. APase activity in the cell pellet and in the supernatant was compared with the activity in the same volume of the whole culture. Enterotoxin production and capability for dark repair of UV-induced DNA damage did not change appreciably in cells grown in LPG medium. APase activity increased following animal passage of strain EW6 relative to that in pre-passaged cells (Fig. 2a). In contrast, enzyme activity was reduced when strain 154 was passaged through animals (Fig. $2 b$ ). No appreciable difference was observed when APase activity in pre- and post-animal passaged strain 569B was examined (Fig. 2c).

During the exponential phase of growth of strain 154 before passage only $50 \%$ of the APase activity of the whole culture was associated with the pellet. After animal passage, this increased to $70 \%$ (Fig. 2 b). The difference was more pronounced with strain $569 \mathrm{~B}$; while more than $90 \%$ of the total activity was detected in the pellet after animal passage, the amount of cell-associated activity was reduced to about $65 \%$ after five to seven subcultures (Fig. $2 c$ ). Animal passage restored the level of recovery of the enzyme activity in the cell pellet. No appreciable difference in the recovery of activity in the cell pellet was observed for strain EW6 before and after passage (Fig. 2a).

Enzyme activity could not be detected in cell-free culture supernatants, and a number of possible explanations for the difference between whole cultures and cell pellets were investigated. To ensure that the incomplete recovery of activity in the cell pellet was not due to lack of any cofactor(s) released into the supernatant, in some experiments the supernatant was added back into the reaction mixture. Such treatment did not result in a better recovery. Also neither toluene treatment nor sonication of cells had an effect on recovery of enzyme activity. To examine whether the loss of activity in cell pellets was due to activation of cell-associated protease(s), the whole culture was treated with phenylmethylsulphonyl fluoride, a serine protease inhibitor, before harvesting and the pellet was suspended in buffer containing the inhibitor up to $5 \mathrm{mM}$. No change in recovery of APase activity in the cell pellet was observed.

The results presented in Table 3 show that although the APase of freshly animal-passaged $569 \mathrm{~B}$ cells was stable, the APase activity of the strain after subculture in vitro decayed rapidly 
Table 3. Stability of APase activity at $0^{\circ} \mathrm{C}$

Cells grown in LPG medium to an $\boldsymbol{A}_{540}$ of $1 \cdot 2$, corresponding to the mid-exponential phase of growth, were kept at $0{ }^{\circ} \mathrm{C}$ and APase activity was assayed at intervals as described in Methods. The results shown are for a single representative experiment; not more than $5 \%$ variation was observed between experiments. The values in parentheses represent APase activity [ $U$ (mg dry wt $)^{-1}$ ] corresponding to $100 \%$ activity.

$\begin{array}{cccc}\begin{array}{c}\text { Time } \\ (\text { min })\end{array} & \text { Strain } & \overbrace{\text { Before passage }} & \text { After animal passage } \\ 0 & \text { EW6 } & 100(140) & 100(220) \\ & 154 & 100(150) & 100(120) \\ & 569 B & 100(190) & 100(190) \\ 10 & \text { EW6 } & 78 & 90 \\ & 154 & 45 & 75 \\ & \text { 569B } & 65 & 95 \\ 20 & \text { EW6 } & 78 & 90 \\ & \text { 154 } & 40 & 70 \\ & \text { 569B } & 60 & 95\end{array}$

Table 4. Summary of results

\begin{tabular}{lcccc}
\multicolumn{1}{c}{ Property } & Manipulation* & EW6 & 154 & $569 \mathrm{~B}$ \\
Enterotoxin production & AP & - & No change & Increase \\
& LM & - & No change & Decrease \\
DNA repair & AP & No repair & No repair & Increase \\
& LM & Slight increase & No repair & Decrease \\
APase activity $\dagger$ & AP & Increase & Decrease & No change \\
Stability of APase $\dagger$ & LM & Decrease & Slight increase & No change \\
& AP & Slight increase & Increase & Increase \\
& LM & Slight decrease & Decrease & Decrease
\end{tabular}

* AP, Animal passage; LM, Laboratory maintenance.

$\uparrow$ Data from Fig. 2.

even at $0{ }^{\circ} \mathrm{C}$. About $40 \%$ of the activity was lost after $20 \mathrm{~min}$. Similar results were obtained by holding cells at $30^{\circ} \mathrm{C}$. In contrast, in strain 154 the enzyme was found to be unstable before and after animal passage. These results also suggest that the incomplete recovery in the cell pellet was not due to protease activation. It thus appears that some modification of the stability of the enzyme in vivo might be responsible for the incomplete recovery.

The observed phenotypic changes occurred after five to seven subcultures. About 30 randomly selected colonies of animal-passaged cells of strain 569B were examined in the present study. In more than $80 \%$ of the single-colony isolates, enterotoxinogenicity, DNA repair capability and APase stability were restored to primary laboratory passage levels simultaneously. In about $20 \%$ of the single-colony isolates, animal passage failed to increase enterotoxin production and at the same time DNA repair capability and stability of APase were not restored. No isolate has yet been examined in which only one of the properties was reinstated. It appears, therefore, that these processes might be interdependent.

The results presented in this report show marked differences in DNA repair capability, stability of APase and enterotoxin production after animal passage of laboratory-maintained strains of $V$. cholerae. While laboratory maintenance had little effect on non-toxinogenic and mildly toxinogenic strains, the above-mentioned properties were either inhibited or reduced in toxinogenic strain 569B along with a reduction in enterotoxin production (Table 4). However, the observations described here do not permit one to draw conclusions at present as to any direct correlation between toxinogenicity and the phenotypic changes observed. 
This investigation was supported by Council of Scientific and Industrial Research and Department of Science and Technology [Grant no. 11(35)/78-SERC]. Two of us (N.K.R.) and (G.D.) are grateful to the Indian Council of Medical Research and the Lady Tata Memorial Trust, respectively, for granting predoctoral research fellowships. We wish to thank members of the Biophysics Division for their help and encouragement and Mr K. N. Maitra for helping us in the animal experiments.

\section{REFERENCES}

Burrows, W., Musteikis, G. M., OzA, N. B. \& DutTA, N. K. (1965). Cholera toxins: quantitation of the frog skin reaction and its relation to enteric toxicity. Journal of Infectious Diseases 115, 1-8.

Craig, J. P. (1971). Cholera toxins. In Microbial Toxins, vol. IIA, pp. 189-254. Edited by S. Kadis, T. C. Montie \& S. J. Ajl. New York: Academic Press.

DAs, G., SIL, K. \& DAS, J. (1981). Repair of ultraviolet light induced DNA damage in Vibrio cholerae. Biochimica et biophysica acta 655, 413-420.

Ganguly, U. \& GREenough, W. B. (1975). Adenosine $\left(3^{\prime}-5^{\prime}\right)$ cyclic monophosphate in Vibrio cholerae. Infection and Immunity 11, 343-349.

GeRDES, J. C. \& RoMig, W. R. (1975). Genetic basis of toxin production and pathogenesis in Vibrio cholerae: evidence against phage conversion. Infection and Immunity 11, 445-452.

HondA, T. \& FinkelsteIn, R. A. (1979). Selection and characteristics of a Vibrio cholerae mutant lacking the A (ADP ribosylating) protein of the cholera enterotoxin. Proceedings of the National Academy of
Sciences of the United States of America 76, 20522056.

KASAI, G. J. \& BURRows, W. (1966). The titration of cholera toxin and antitoxin in rabbit ileal loop. Journal of Infectious Diseases 116, 606-614.

MUKherJeE, S. (1978). Principles and practice of typing Vibrio cholerae. Methods in Microbiology 12, 74-115.

Richards, K. L. \& Douglas, S. D. (1978). Pathophysiological effects of Vibrio cholerae and enterotoxinogenic Escherichia coli and their exotoxins on eucaryotic cells. Microbiological Reviews 42, 592-613.

RoY, N. K., GHosh, R. K. \& DAS, J. (1982). Repression of the alkaline phosphatase of Vibrio cholerae. Journal of General Microbiology 128, 349-353.

SELWYN, M. J. (1965). A simple test for inactivation of an enzyme during assay. Biochimica et biophysica acta 105, 193-195.

Wilson, G. S. \& Miles, A. (1975). Principles of Bacteriology, Virology and Immunity, vol. 1. London: Edward Arnold. 